send

z Research Square

\title{
Development and Evaluation of a Novel Fast Broad-Range ITS/LSU DNA PCR and Sequencing Assay (FBR-PCR/S) for Rapid Diagnosis of Invasive Fungal Diseases: Multi-Year Experience in a Large Canadian Healthcare Zone and a Literature Review
}

\section{B Chow}

Calgary Laboratory Services

M Groeschel

University of Calgary

J Carson

University of Calgary

Thomas Griener

Calgary Laboratory Services

Deirdre Church ( $\nabla$ dchurch@ucalgary.ca )

University of Calgary

Research Article

Keywords: fungal infection, broad-range fungal PCR, sequencing, molecular diagnosis

Posted Date: November 18th, 2021

DOI: https://doi.org/10.21203/rs.3.rs-1009236/v1

License: (c) (1) This work is licensed under a Creative Commons Attribution 4.0 International License. Read Full License 


\section{Abstract}

\section{Background}

This study evaluated the performance of a novel fast broad range PCR and sequencing (FBR-PCR/S) assay for the improved diagnosis of invasive fungal disease (IFD) in high-risk patients in a large Canadian healthcare region.

\section{Methods}

A total of 114 clinical specimens (CS) including bronchoalveolar lavages (BALs) were prospectively tested from 107 patients over a 2-year period. Contrived BALs $(n=33)$ inoculated with known fungi pathogens were also tested to increase diversity. Patient characteristics, fungal stain and culture results were collected from the laboratory information system. Dual-priming oligonucleotide (DPO) primers targeted to the ITS ( 350 bp) and LSU ( 550 bp) gene regions were used to perform FBR-PCR/S assays on extracted BALs/CS. The performance of the molecular test was evaluated against results of fungal stains and culture, and where available, histopathology, and clinical review for the presence of IFD.

\section{Results}

The 107 patients were predominantly male $(67,62.6 \% \%)$ with a mean age of $59 \mathrm{yrs}$. (range $=0$ to $85 \mathrm{yrs}$.): 74 (69.2\%) patients had at least one underlying comorbidity: 19 (34.5\%) had confirmed and $12(21.8 \%)$ had probable IFD. Culture recovered 66 fungal isolates from 55 BALs/CS with Candida spp. and Aspergillus spp. being most common. For BALs, the molecular assay vs. fungal culture had sensitivity, specificity, positive predictive value (PPV) and negative predictive value (NPV), and efficiency of $88.5 \%$ vs. $100 \%, 100 \%$ vs. $61.1 \%, 100 \%$ vs. $88.5 \%, 61.1 \%$ vs. $100 \%$, and $90.2 \%$ for both. For other CS, the molecular assay had similar performance to fungal culture with sensitivity, specificity, PPV, NPV and efficiency of $66.7 \%, 87.0 \%, 66.7 \%, 87.0 \%$ and $81.3 \%$ for both methods. Both methods also performed similarly, regardless of whether CS stain/microscopy showed yeast/fungal elements. FBR-PCR/S assays results were reported in $~ 8 \mathrm{~h}$ compared to fungal cultures that took between 4 to 6 weeks.

\section{Conclusions}

Rapid molecular testing compared to culture has equivalent diagnostic efficiency but improves clinical utility by reporting a rapid species-level identification the same dayshift ( 8h).

\section{Background}

Invasive fungal disease (IFD) has increased significantly in the last few decades due to the expansion of patients with acquired immunosuppression(1-3). IFD results in increased morbidity and mortality and higher healthcare costs(4-9). Delayed diagnosis is associated with poor clinical outcomes because appropriate treatment measures are not promptly started(1, 10-12). However, IFD is often difficult to diagnose because clinical and radiographic findings are non-specific and traditional microbiological methods such as fungal culture have low sensitivity ranging from 30-60\%(13-15). Too frequently, tissues or body fluids are harvested by invasive procedures, and all or most of the specimen is sent to pathology for formalin fixation with limited or no tissue being sent for cultures(13). This erroneous clinical practice negates making a microbiological diagnosis of IFD and impedes the ability to properly treat the infection based on a genus- and -species pathogen identification. Fresh tissue biopsies are often required to confirm the presence of IFD but specimen processing and homogenization break-up hyphae lowering the recovery of viable microorganisms from cultures. Fungi can also not be accurately identified from stained histopathology or cytology sections, and the lack of concordance between pathology and culture results is well recognized(15-17). Identification of the causative pathogen is important for targeting antifungal therapy as well as determining prognosis. Culture-independent microbiology assays for reliable detection and identification of a wide-range of fungal pathogens are urgently needed to improve clinical outcomes of IFD.

Broad-range sequencing of fungal DNA has been used as an alternate approach for diagnosing IFD in high-risk patients where delayed appropriate therapy may cause worse outcomes(18-20). Because our regional clinical microbiology laboratory provides services to a wide variety of immunosuppressed patients (e.g., hematological malignancy, HSCT, SOT, diabetes, solid-tumour 
malignancy, HIV/AIDS, and immunotherapy), it was important to implement broad-range PCR/sequencing to enable rapid fungal identification to ensure appropriate therapy because culture take between 4-6 weeks to complete. Prior reports using conventional primers have shown broad range fungal PCR and sequencing targeted to one or more regions of the fungal multicopy ribosomal RNA (rRNA) such as 18S rRNA, D1and D2 regions of 28s rRNA, 5.8S rRNA, and internal transcribed spacers 1 and 2 (ITS1 and ITS2) allowed variable detection and identification of fungi in clinical specimens(20-25). Additionally, clinical specimens routinely tested by fungal culture may be highly contaminated by commensal flora(15), and their human DNA may cross-react in broad-range assays(26). We developed and evaluated a novel fast broad-range dual target DNA PCR and sequencing assay using unique dual-priming oligonucleotide (DPO) primers to try and increase assay specificity while decreasing the time to reported results(26). Our clinical microbiology laboratory previously developed and implemented broad-range PCR for bacterial $16 \mathrm{~S}$ ribosomal DNA and sequencing using 16S rDNA DPO primers that allows robust sensitivity while improving specificity due to elimination of cross-reactivity with human material(27). The novel FBR-PCR/S assay described herein uses similar fast protocols, DPO primers and procedures to integrate workflow efficiency for technologists performing both the bacterial and fungal broadrange PCR/cycle sequencing assays within a standard $\sim 8 \mathrm{~h}$ dayshift, which allows same day reporting of results from either or both assays.

In this multi-year study, we evaluated the performance of our novel FBR-PCR/S assay by comparing it with the results of fungal stains, culture, and conventional broad-range ITS PCR using bronchoalveolar lavages (BALs) and a variety of other clinical specimens in patients with and without suspected IFD. A literature review was also done to compare our result to previously published studies of other laboratory-developed assays, and recently published evaluations of commercial PCR tests.

\section{Materials And Methods}

\section{Study setting and patients}

The Calgary Zone, Alberta Health Services (AHS), is one of the largest integrated healthcare jurisdictions in Canada, which provides care to an urban and rural population of $~ 1.5$ million people. Our novel fast fungal BR-PCR/S assay was developed and pre-clinically validated using retrospectively collected and saved clinical samples from patients suspected to have IFD that had either had positive fungal cultures for a wide variety of yeasts and molds or had been inoculated with known fungal isolates. Patients with and without suspected non-invasive and IFD were then prospectively enrolled over a two-year period (2016-18) based on combined concern of the consulting Infectious Diseases physician for IFD, and the results of fungal stains and culture. Cases were categorized as having confirmed IFD, probable IFD or no fungal disease in the context of clinical review and microbiological work-up (microscopy, culture, and PCR/sequencing). Data were obtained by medical microbiologists (MG and JC) and an infectious diseases specialist (DLC). Data were assessed against previously published clinical and laboratory criteria to inform an expert diagnostic decision(28).

\section{Laboratory setting and specimens}

Microbiology testing was performed by the Clinical Section of Microbiology, Calgary Laboratory Services (CLS; Alberta Prevision Laboratories). APL-CLS is a large regional centralized laboratory that performs diagnostic testing for the entire Calgary Zone, including all ambulatory, hospitalized and long-term care patients. Our laboratory also acts as the primary Mycology testing laboratory for Southern Alberta including major rural cities and townships representing a population of $\sim 600 \mathrm{~K}$.

To broaden the diversity of specific fungi detected by our assay, fungal isolates $(n=33)$ with known genus- or species-level identifications were obtained from our reference mycology laboratory [Provincial Laboratory Northern Alberta (PLNA), Edmonton, AB] including: Aspergillus lentulus $(\mathrm{n}=1)$, A. terreus $(\mathrm{n}=3)$, A. flavus $(\mathrm{n}=3)$; Absidia corymbifera $(\mathrm{n}=3)$; Fonsecaea pedrosoi $(\mathrm{n}=2)$; Fusarium solani $(\mathrm{n}=2)$, F. proliferatum $(\mathrm{n}=1)$; Cladosporium carrionii $(\mathrm{n}=2)$ and Cladosporium $\mathrm{spp} .(\mathrm{n}=1)$; Cunninghamella bertholletiae $(\mathrm{n}=2)$ and one undetermined Cunninghamella spp.; Rhizopus aarhizus $(\mathrm{n}=1), R$. microsporus $(\mathrm{n}=1)$, R. stolonifera $(\mathrm{n}=1)$, and three undetermined Rhizomucor spp.; Trichosponon asahii $(\mathrm{n}=1)$ and one undetermined Trichosporon spp.; and Malassezia furfur $(n=2), M$. pachydermatis $(n=1)$. These isolates were used for the pre-clinical validation to inoculate spent fungal-negative bronchoalveolar lavage specimens (BALs) that would otherwise have been discarded once clinical testing was complete. 
A total of 114 enrolled clinical specimens were categorized as sterile tissues, non-sterile tissues, and sterile body fluids (Table 1). A variety of specimens were enrolled including those from patients with and without suspected IFD that had negative or positive fungal stain/culture results, or a positive stain but negative culture result. Bronchoalveolar lavages (BALs) are collected by experienced pulmonary medicine, critical care, and thoracic surgery specialists according to a standardized regional protocol that sets out the amount of fluid, and collection procedures to be used. All other sterile fluid and tissue specimens were collected by appropriate sterile techniques, and promptly transported to the microbiology laboratory within $2 \mathrm{~h}$ after collection. A Microbiologist (DLC/TG/MG) approved their quality before enrollment. Study specimens were stored at -80 to $-86^{\circ} \mathrm{C}$ and batched for DNA extraction.

\section{Fungal stain and culture}

Clinical specimens were analyzed by microscopy and culture methods for the presence of fungi. Calcofluor-White (CW) stain (i.e., CW-Evans blue reagent) with $10 \%$ potassium hydroxide was performed on tissue homogenates and sterile body fluids. CWstained slides were air-dried then fixed with methanol before reading within $24 \mathrm{~h}$ of preparation under fluorescent microscopy. Tissue biopsies obtained via open resection were minced for culture. Specimens were inoculated onto general mycology media including inhibitory mold agar (IMA) (Oxoid \# MP0950), brain heart infusion agar (BHI) with 5\% sheep blood (Oxoid \#MP0234) and $\mathrm{BHI}$ with antibiotics (BHIA) (i.e., chloramphenicol, gentamicin and cycloheximide) (Oxoid \#MP0237) and incubated in $\mathrm{O}_{2}$ at $30^{\circ} \mathrm{C}$. In addition, BALs and bronchial wash specimens were inoculated to buffered charcoal yeast extract (BCYE) agar (Oxoid \#MP1201). Cultures were assessed for growth daily for the first 5 days and then biweekly for up to 42 days. Positive cultures were identified using various methods including macroscopic colony morphology and microscopic examination, VITEK 2 Yeast ID card (bioMérieux, Laval, Quebec), matrix-assisted laser desorption/ionization-time-of-flight mass spectrometry (MALDI-TOF MS) (bioMérieux, Laval, Quebec), and separate PCR/sequencing analysis at the PLNA reference laboratory using the commercial MicroSEQ ${ }^{\text {TM }}$ D2 rDNA Fungal PCR and Sequencing Kit (Applied Biosystems, Thermo Fisher Scientific).

Some specimens only had a bacterial work-up (Gram stain, culture under aerobic and anaerobic environmental conditions) because fungal culture was not initially ordered by the physician but subsequently one or more yeast/molds grew. An FBR$\mathrm{PCR} / \mathrm{S}$ assay was subsequently done to confirm the presence of each recovered yeast/mold species.

\section{Molecular Methods}

A clinical isolate of Saccharomyces cerevisiae positive in the FBR-PCR/S assay for both ITS2 and LSU targets was used as the positive control throughout all DNA extraction and FBR-PCR/S assay procedures. The negative extraction control (i.e., extraction reagents only; NEC) was processed and extracted alongside all clinical samples including those inoculated with known fungal isolates. NEC negative control was used throughout all FBR-PCR/S assay procedures.

\section{DNA Extraction}

a. Fungal Isolates: Fungal isolates obtained from the reference laboratory were extracted in TE buffer using glass beads and bead beating. The DNA concentration of the fungal nucleic acid extract was determined using a Nanodrop spectrophotometer (Thermo-Fisher Scientific, Mississauga, Ont.). A total of $500 \mathrm{ng}$ DNA was eluted into $100 \mu \mathrm{L}$ of TE buffer giving a final template concentration of $5 \mathrm{ng} / \mu \mathrm{L}$. This amount of fungal DNA was required for reliable detection in the FBRPCR/S assay. Contrived specimens $(n=33)$ were prepared by adding $500 \mathrm{ng}$ reference isolate DNA to $400 \mu \mathrm{L}$ of spent BAL fluid about to be discarded after completion of clinical testing. The contrived specimens containing 'inoculated' reference isolate DNA were then extracted using the QIAmp UCP Pathogen Mini Kit (Canada-QIAGEN, Toronto, CA). Fungal $\mathrm{PCR} /$ sequencing testing was then performed according to the method outlined below. Based on testing of these BALs with a known amount of fungal inoculum, the FBR-PCR/S assay had a limit of detection of 35 ng of DNA or 1,000 copies/mL.

b. Clinical Specimens: Clinical tissue and fluid specimens were extracted using QIAmp UCP pathogen Mini Kit (QIAGEN). Tissues had an extended Proteinase K incubation time, otherwise both tissue and fluid protocols were the same. Briefly, a representative tissue specimen of 2-4 $\mathrm{mm}^{3}$ was finely minced with sterile scalpel and transferred to a sterile $1.5 \mathrm{~mL}$ microcentrifuge tube, re-suspended in $400 \mu \mathrm{L}$ Buffer ATL and $40 \mu \mathrm{L}$ kit-supplied Proteinase K. Tissue specimens were then briefly vortexed and incubated at $56^{\circ} \mathrm{C}$ in a $1000 \mathrm{rpm}$ Eppendorf thermomixer for a minimum of $1 \mathrm{~h}$ until the tissue was 
digested. A minimum $400 \mu \mathrm{L}$ aliquot of each sterile fluid specimen was placed into a sterile $1.5 \mathrm{~mL}$ microcentrifuge tube

and centrifuged, supernatant discarded, and cell pellet re-suspended in Buffer ATL, Proteinase K. Sterile fluid specimens were then briefly vortexed and incubated at $56^{\circ} \mathrm{C}$ in a $1000 \mathrm{rpm}$ Eppendorf thermomixer for a minimum of $10 \mathrm{~min}$. DNA in the proteolytic digests were further purified according to the manufacturer's instructions. DNA was eluted from tissues and fluids in $150 \mu \mathrm{L}$ and $100 \mu \mathrm{L}$ of Buffer AVE, respectively. DNA was stored at $-20^{\circ} \mathrm{C}$ until use.

\section{FBR-PCR/S Assay}

FBR-PCR/S was performed using dual priming oligonucleotide (DPO) primers providing a short and long read that were targeted towards the Internal Transcribed Spacer (ITS) regions and the Large Subunit (LSU) of the nuclear ribosomal RNA (rRNA) gene complex $(26,27)$. All DPO primers were purchased from Exiqon (Woburn, MA). FBR-PCR consisted of a forward primer [ITS3DPO_F3: 5' CAT CGA TGA AGA RCG YA-I-I-I-I-I-TGCGA 3' (I=deoxyinosine; R=A/G, Y=C/T)], and two reverse primers, for ITS detection [ITS4DPO_R5: 5' TAT TGA TAT GCK TAA-I-I-I-I-G CGG GT 3' (K=G/T), and LSU detection [LSUDPO3_R: 5' GAC TCC TTG GTC CGT-III-II-AAG AC 3'. PCR for human- $\beta$-globin gene was performed in parallel as a control using $\beta$-glob-F [GAAGAGCCAAGGACAGGTAC] and $\beta$-glob-PC04R [CAACTTCATCCACGTTCACC] in a final concentration of $0.3 \mu \mathrm{M}$.

Fast-PCR was set up with the Molyzm 16S basic (Molzym, Bremen, Germany) kit reagents. The $30 \mu \mathrm{L}$ reaction contained $7 \mu \mathrm{L}$ of template DNA and final concentration of $0.3 \mu \mathrm{M}$ ITS3DPO_F3 forward primer and $0.2 \mu \mathrm{M}$ each of ITS4DPO_R5 and LSUDPO3_R reverse primer. FBR-PCR was performed on a Veriti thermocycler (Life Technologies, Carlsbad, CA) under the following cycling conditions: $5 \mathrm{~min}$. initial denaturation at $95^{\circ} \mathrm{C}$, followed by 35 cycles of $94^{\circ} \mathrm{C}$ for $10 \mathrm{~s}, 54^{\circ} \mathrm{C}$ for $15 \mathrm{~s}$ and $72^{\circ} \mathrm{C}$ for $25 \mathrm{~s}$, with a final extension of $72^{\circ} \mathrm{C}$ for $5 \mathrm{~min}$. PCR product was electrophoresed on a $1.5 \%$ agarose gel containing SYBRsafe (Life Technologies). During the PCR reaction, the ITS3DPO_F3/ITS4DPO-R5 F/R primer pair amplify a 350 bp ITS amplicon, whereas the ITS3DPO_F3/LSUDPO_3R F/R primer pair amplify the ITS region (350 bp) plus 500-600 bp of the LSU region. The 900 bp amplicon therefore represented a combined ITS/LSU fragment. Agarose gel electrophoresis confirmed the amplification of fungal DNA: PCR products displaying a band in the expected $~ 350$ bp region for ITS and $\sim 900$ bp region for ITS/LSU were then purified by Exo-SAP-it (Affymetrix, Santa Clara, CA).

Molecular identification of the ITS and LSU rDNA product(s) was done by Sanger sequencing of the ITS and/or LSU rDNA product using DPO primers and BigDye Terminator v1.1 Cycle Sequencing Kit (Life Technologies) on an ABI Prism 3500XL sequencer (Life Technologies). The ITS3DPO_F3/ITS4DPO-R5 F/R primer pair was used to sequence the ITS region and the LSU-Fseq [AGTARCGGCGAGTGAAG]/ LSUDPO3_R F/R primer pair were used to sequence the LSU region. A BLAST search against the IDNS Fungal database (SmartGene IDNS, Lausanne, Switzerland) provided a definitive identification of the organism to the genus- or species-level using the identify scores outlined by the Clinical Laboratory Standards Institute, Approved Guidelines MM-18(29).

\section{Data analysis}

Data were entered into a Microsoft Excel spreadsheet (MS Office 2013) and analyzed according to standard descriptive statistics. A 2 X 2 contingency table was used to calculate the sensitivity, specificity, positive and negative predictive values were calculated using the confirmed or possible clinical diagnosis of IFD based on expert clinical review of each case against internationally recognized diagnostic criteria(28). Performance was calculated using both FBR-PCR/S and fungal culture as the "gold standard" method, because the later is a broad amplifier of both pathogenic, commensal, and contaminating flora and may not be an accurate reflection of the clinical relevance of recovered isolates. Invalid FBR-PCR/S results were defined as a weakly positive electrophoresis band in either of the LSU/LSU fungal targets with no quality sequence subsequently obtained. A true positive FBR-PCR/S result was one where fungal culture and the molecular assay detected the same microorganism(s) in a patient with suspected, possible, or confirmed IFD. A false-negative molecular result was one where a yeast/fungus was recovered in culture that was not detected by the molecular assay. A false-positive molecular result was one where the FBR$\mathrm{PCR} / \mathrm{S}$ assay detected a fungus, there was no growth on fungal culture, and the patient had no evidence of infection. If there was not complete agreement between the fungal culture and molecular assay, results were considered discordant. Resolution of discordant results occurred by repeat FBR-PCR/S testing, repeat testing using conventional ITS primers, and clinical review. 


\section{Results}

\section{Patient characteristics and specimens}

A total of 107 enrolled patients were predominantly male $(67,62.6 \%)$. The mean age of $59 \mathrm{yrs}$. (range $=0$ to $85 \mathrm{yrs}$.) and there was no significant age difference according to gender. Comorbidities in five patients were unknown due to missing data. Most patients $(74 / 107,69.2 \%)$ had at least one underlying comorbidity that predisposed them to IFD including diabetes mellitus (18/74, 24.3\%), solid-organ malignancy/tumour (18/74, 24.3\%), immunosuppressive therapy for non-malignant conditions (13/74, 17.6\%), hematologic malignancy (12/74, 16.2\%), hematopoietic stem cell transplant (HSCT) (5/74, 6.7\%), HIV/AIDs (4/74, $5.4 \%)$, and end-stage renal disease (2/74, $2.7 \%)$. A total of 19 patients $(17.8 \%)$ had confirmed IFD, another $12(11.2 \%)$ had probable IFD, and the rest had no evidence of infection. Approximately one-third $(15 / 54,27.8 \%)$ of the true positive molecular tests for any yeast/fungi were found in patients with confirmed or probable IFD.

A total of 114 clinical specimens were tested from these patients including 39 (34.2\%) BALs and 75 (65.8\%) other types of sterile fluids and tissues; 7 patients had $\geq 2$ specimens tested (Table 1). BALs and other pulmonary specimens (lung/bronchial/pleural aspirates or fluids) ( $n=51,44.7 \%)$ were the most tested sterile fluids. A wide range of different tissue types were tested representing the disseminated nature of IFD. A total of $55(48.2 \%)$ specimens had yeast/fungi recovered from fungal cultures. Twenty (17.5\%) specimens only had bacterial cultures done because yeast/fungal culture was not ordered - most of these specimens $(n=16,80 \%)$ had negative Gram and CW stains and bacterial cultures, but 1 BAL and 2 abdominal fluid specimens grew Candida albicans (despite negative CW), 1 abdominal fluid showed yeast in the Gram stain and grew C. albicans, and 1 sinus aspirate grew Aspergillus fumigatus.

\section{Fungi identified from contrived and clinical specimens}

The FBR-PCR/S assay accurately identified 32/33 (97\%) of the yeast/fungi inoculated into the contrived BAL specimens except for one specimen containing $A$. terreus (See Methods). Another sixty-six fungal isolates were recovered from fifty-five clinical specimens. Candida spp. $(\mathrm{n}=36,54.5 \%)$ [C. albicans $(\mathrm{n}=18)$, C. dublinensis $(\mathrm{n}=4)$, C. glabrata $(\mathrm{n}=5)$, C. kefyr $(\mathrm{n}=3)$, C. krusei $(\mathrm{n}=2)$, C. parapsilosis $(\mathrm{n}=1)$ and C. tropicalis $(\mathrm{n}=2)]$ and Aspergillus spp. $(\mathrm{n}=14,16.7 \%)$ [A. flavus $(\mathrm{n}=2), A$, fumigatus $(\mathrm{n}=7), A$. terreus $(\mathrm{n}=1)$, A. niger $(\mathrm{n}=1)$, and 3 other Aspergillus spp.] were the most identified species either fungal culture or FBR-PCR/S. Other fungal species identified included Alternaria spp. $(n=1)$, Coccidioides immitis $(n=2)$, Cryptococcus neoformans $(n=1)$, Exophilia dermatiditis $(\mathrm{n}=1)$, Fonsecaea spp. $(\mathrm{n}=1)$, Fusarium merismoides $(\mathrm{n}=1)$, Histoplasma capsulatum $(\mathrm{n}=1)$, Penicillium spp. $(\mathrm{n}=2)$, Pseudallescheria boydii complex $(\mathrm{n}=2)$, Trichophyton rubrum $(\mathrm{n}=1)$ and Rhizopus oryzae $(\mathrm{n}=3)$. One BAL sample was also PCR positive for Pneumocystis jirovecii using specific PCR primers.

\section{Resolution of discrepant results}

Discordant results were initially observed in 30 clinical specimens including 16 BALs and 14 other types of clinical specimens. Table 2 details the resolution of discrepant results. Of the 30 discordant results, 19 (63.3\%) specimens [BALs $(n=10)$ and other clinical specimens $(n=9)$ ] were resolved in favour of the molecular assay results (Table 2A), while 11(36.7\%) specimens [BALs $(n=6)$ and other clinical specimens $(n=5)]$ were resolved in favour of fungal culture results (Table 2B). BALs were prone to contamination from patient's airway colonization with Candida spp. and/or Aspergillus spp., which gave initial discrepant results, but most were resolved in favour of the FBR-PCR/S result after repeat testing and clinical review (Table 2A).

FBR-PCR/S analysis made a critical difference to patient management and clinical outcome in 4 unusual cases where fungal cultures were negative (Table 2A). Brain, cheek, and parotid tissue (Specimens 11 to 13) were harvested in the operating room from a critically ill 25 yo diabetic female with rapidly progressive severe necrotizing left facial and sinus infection where sequential specimens remained culture negative but broad-based aseptate hyphae were seen on Grocott's stains in histopathology sections(30). Rapid PCR diagnosis of rhino cerebral Mucormycosis dure to Rhizopus oryzae allowed optimal treatment and management. For Specimen 15, FBR-PCR/S results allowed appropriate management of this patient's intraabdominal abscesses and institution of anti-fungal therapy with cessation of broad-spectrum antibacterial agents. Specimen 18 was harvested under ultrasound guidance in a 49 yo female with a new onset acute myelogenous leukemia and large hepatosplenic lesions thought to be due to candidiasis that were fungal/bacterial culture negative. Diagnosis of hepatosplenic 
Mucormycosis due to Rhizomucor pusillus enabled immediate appropriate anti-fungal management and drainage, and the patient proceeded to allogenic stem cell bone marrow transplant. Although specimen 19 fungal cultures eventually grew scant amounts of Histoplasma capsulatum after almost 6 weeks of incubation, FBR-PCR/S testing allowed for rapid confirmation of Histoplasmosis, which was also consistent with histopathology sections showing yeast with broad-based budding on Grocott's and PAS stains.

\section{Molecular Assay Performance}

The performance of the molecular assay compared to fungal culture is shown in Table 3A for BALs, and Table 3B for other clinical non-BAL specimens. For BALS, the FBR-PCR/S assay had sensitivity, specificity, positive predictive value (PPV) and negative predictive value (NPV) of $88.5 \%, 100 \%, 100 \%$ and $61.1 \%$ compared to culture. Fungal culture had sensitivity, specificity, positive predictive value (PPV) and negative predictive value (NPV) of 100\%, $61.1 \%, 88.5 \%$ and $100 \%$ compared to the molecular assay for BALs. Overall, fungal culture and the molecular assay had similar diagnostic efficiency ( $90.2 \%)$ for BAL specimens (Table 3A).

For other clinical specimens, the FBR-PCR/S assay and fungal culture had similar performance with sensitivity, specificity, positive predictive value (PPV) and negative predictive value (NPV) of $66.7 \%, 87.0 \%, 66.7 \%$ and $87.0 \%$ compared to culture. Overall, fungal culture and the molecular assay had similar diagnostic efficiency (81.3\%) for other types of clinical specimens (Table 3B).

Table $\mathbf{3 C}$ shows that fungal culture and the molecular detection had similar performance compared to whether the clinical specimen showed fungal elements on CW stain and microscopic examination. Although a negative CW stain and microscopic examination has excellent specificity and NPV, it has poor sensitivity and PPV for fungal infection. Both BALs and other clinical specimens with negative culture and PCR results were microscopy negative. Although specimens positive by microscopy ( $n=10$, $8.8 \%$ ) demonstrated variable culture and/or PCR positivity; 6 specimens were positive by both methods, 2 were only positive by culture, and 2 were only positive by PCR. Another fifty-six (49.1\%) specimens were microscopy negative but grew a variety of yeast/fungi and demonstrated variable culture and/or PCR positivity; 37 were positive by both methods, 14 were only positive by culture and 5 were only positive by PCR.

\section{Implementation of the Molecular Assay}

Figure 1 shows an overview of the FBR-PCR/S procedure workflow and the time required for each assay step. The FBR-PCR/S assay workflow uses fast-PCR protocols and automated commercial sequence alignment and interpretation so that results can be reported in $\sim 8 \mathrm{~h}$ or within the technologist's dayshift; divided between specimen processing/extraction and fast PCR amplification/gel interpretation $(\sim 4.5 \mathrm{~h})$ and fast cycle sequencing and interpretation ( 3.5 h) (Figure 1). Due to the longer sequence length provided by the LSU primers ( $>550 \mathrm{bp}$ ) this would be the preferred single target for initial detection followed by ITS ( 350 bp). To ensure an optimal pre-test probability and the quality and quantity of specimen available FBR-PCR/S tests should be ordered by the Infectious Diseases service in consultation with a clinical microbiologist.

\section{Literature Review}

Previous reports of FBR-PCR/S evaluations in non-selected clinical cases have been limited, and primarily reported from large laboratories in Europe of the United States(18, 21-23, 31). Lass-Florl and colleagues(2013/Austria)(18) evaluated an ITS fungal PCR in 206 tissues and sterile fluid samples ( $\mathrm{n}=190$ patients) with negative microscopy and found a sensitivity, specificity, PPV and NPV of $57.1 \%, 97 \%, 80 \%$ and $91.7 \%$. Valero and colleagues(2016/Spain)(23) developed a fungal PCR using two ITS primers and 4 probes specific for specific fungal pathogen groups and testing of 60 tissue and sterile fluid samples showed comparable sensitivity (83.3\%) and specificity (100\%) to our assay. Zeller and colleagues (2017/Austria) (20) evaluated an ITS fungal PCR in 105 tissues and sterile fluids ( $n=98$ patients) and found a sensitivity, specificity, PPV and NPV of $87.7 \%, 90.3 \%, 76 \%$ and $95.5 \%$ respectively. Gomez and colleagues (2017/USA) (22) used a dual target (i.e., ITS 2 and D2 region of 28S) to evaluate 117 tissues and sterile fluids from 117 patients with confirmed IFD compared to 116 clinical samples from 108 patients with suspected IFD. Performance of their fungal PCR assay was better in the targeted IFD group [sensitivity (96.6\%) and specificity (98.25\%)] than in patients suspected of IFD [sensitivity (62.8\%) and specificity (71.3\%)](22). Ala-Houhala and colleagues (2017/Finland)(21) used 
a dual target ITS fungal PCR to test 37 tissue and sterile fluid specimens from 279 patients and found a sensitivity, specificity, PPV and NPV of $60.5 \%, 91.7 \%, 54.2 \%$ and $93.4 \%$ respectively. Stempak and colleagues (2019/USA) (31) also showed that fungal PCR testing had equivalent performance on analyses of 65 sterile fluid and tissue samples selected based on having all reference methods done (i.e., stains, DNA probes, culture, histopathology). This group did not recommend the routine use of fungal PCR however, because no IFD cases were found that were not diagnoses by the reference methods, and the referred out molecular assay had a prohibitive cost.

Fungal PCR had an excellent performance compared to culture in microscopy positive specimens, and an equivalent performance in microscopy negative specimens. In fact, most patients with IFD were diagnosed by fungal PCR analysis of microscopy negative specimens so testing should be done in non-selected patients without overt immunosuppression. Rampini and colleagues (2016/Switzerland)(19) have also demonstrated similar efficacy of their fungal ITS PCR compared to conventional fungal culture for diagnosing fungal infections in non-immunocompromised patients. They evaluated $251 \mathrm{clinical}$ specimens using both the fungal ITS PCR compared to fungal culture and demonstrated a high concordance of $89.6 \%$ and equivalent analytical performance with a sensitivity, specificity, PPV and NPV of $87.7 \%, 90.3 \%, 76 \%$ and $95.5 \%$ respectively(19).

\section{Discussion}

Accurate diagnostic of IFD is critical to prompt, appropriate anti-fungal and surgical management to achieve the best clinical outcome for these serious infections. Although fungal culture remains the "gold standard" diagnostic method available in most clinical microbiology laboratories, this study and others demonstrate that molecular testing has an equivalent, and in some cases improved performance for direct specimen analyses(19-23). However, a major clinical advantage of our fast PCR protocol, is provision of a result in a day (i.e., a single 8-h daytime shift) compared to culture that can take 4 to 6 weeks $(13,14)$. Without a rapid laboratory confirmation of IFD, clinicians must rely on clinical review and histopathology results, which may not provide a definitive diagnosis.

Our study is the only one performed in a large Canadian healthcare region that has evaluated FBR-PCR/S directly from samples for the rapid detection of suspected IFD. Our unique fungal PCR based on dual target (ITS and LSU) detection using DPO primers and fast protocols allows equivalent or improved diagnostic performance previously reported from other centers who have developed molecular detection assays. Use of a DPO primer approach increased specificity compared to previously reported fungal PCR assays.

However, fungal PCR analysis must be interpreted against the pre-test likelihood of IFD because specific sample types may have a high rate of fungal contamination as shown by the initial rate of discordant results in this study. Most of these samples, not surprisingly, were bronchoalveolar lavage or other pulmonary samples where harvesting may lead to contamination from commensal fungi in the patient's airway, particularly Candida spp. Penicillium spp. and Aspergillus spp. This has also been reported by other investigators who used panfungal PCR to detect and identify fungi in BAL fluids from immunocompromised patients $(15,32)$. Polymicrobial yeast/fungal infections are also difficult to diagnose using PCR because mixed sequencing results may not be interpretable. Culture is a broad amplifier of both pathogens and contaminants as demonstrated in our study where approximately one-third of clinical BALs grew more than one type of fungi, but PCR was only positive for one of them, and the others were often deemed on resolution as contaminants. Even in cases where a single fungus such as Aspergillus spp. is detected in a BAL, clinical correlation must be done to determine whether either the conventional or molecular test result is relevant.

Our study had several limitations including the small number of specimen types and sources enrolled. Because most clinical specimens recover Candida spp. and Aspergillus spp. as the most commonly isolated yeast/fungi, we used mock BAL specimens to broaden the evaluation of the fungal PCR to detect other important yeast/fungal pathogens. Formal chart reviews of each enrolled patient were not done, which may have provided a more detailed clinical assessment of the presence or absence of IFD.

Broad-range FBR-PCR/S analyses targeted to high-risk patients and non-selected non-immunocompromised patients allows for rapid diagnosis of IFD (i.e., $24 \mathrm{~h}$ using a fast PCR protocol), and may identify rare types of fungal disease in critically ill patients whose work-up by fungal reference methods is negative. Microscopic examination does not help the clinical laboratory select

Page $8 / 20$ 
samples for molecular analyses because most cases of IFD have negative results but culture and/or fungal PCR show infection. Laboratories using FBR-PCR/S for diagnosis must consult the physician and correlate discordant results against the patient's likelihood of IFD. Interpretation of molecular assay results must be done with the recognition that specific types of clinical specimens harvested from "sterile" sites may be contaminated with normal commensal fungi. However, use of a DPO primer approach for fungal PCR assay development increases specificity and decreases detection of contaminants.

\section{Conclusions}

Rapid FBR-PCR/S testing has equivalent diagnostic efficiency compared to fungal culture with improved specificity, but our novel assay improves clinical utility by reporting a rapid species-level identification the same dayshift ( 8h).

\section{Abbreviations}

FBR-PCR/S: fast broad range PCR and sequencing; PCR: polymerase chain reaction; bronchoalveolar lavage (BAL); CS: clinical specimens; CSF: cerebrospinal fluid; IFD: invasive fungal diseases; CW: calcofluor white stain; ITS: internal transcribed spacer region; LSU: large subunit region; DNA: deoxyribonucleic acid; NEC: negative extraction control; PEC: positive extraction control; DPO: dual priming oligonucleotides; IMA: inhibitory mold agar; BHI: brain heart infusion agar; BHIA: brain heart infusion agar with antibiotics; BCYE: buffered charcoal yeast extract agar; HIV/AIDS: human immunodeficiency virus/acquired immunodeficiency syndrome; HSCT: hematopoietic stem cell transplant; SOT: solid organ tumour; PPV: positive predictive value; NPV: negative predictive value.

\section{Declarations}

\section{Ethics approval, guidelines, and consent to participate}

The study was approved, and a waiver of informed consent was granted by the Conjoint Health Ethics Research Board (CHREB), Alberta Health Services, and the University of Calgary (Ethics ID: E-23969). All methods were carried out in accordance with relevant guidelines and regulations.

\section{Consent for publication}

Not applicable

\section{Availability of data and materials}

The data that support the findings of this study are available from Alberta Health Services (AHS), Alberta Precision Laboratories $(A P L)$ (formerly CLS) but restrictions apply to the availability of these data, which were used under the ethics agreement for the current study, and so are not publicly available. Data are however available from the author upon reasonable request and with permission of AHS/APL.

\section{Competing interests}

None of the authors have a conflict of interest.

\section{Funding}

Financial support was provided by a peer-reviewed grant from Calgary Laboratory Services (CLS; now Alberta Precision Laboratories).

\section{Authors contributions}

BC, TG and DLC developed the study design, execution, oversight, data analysis and were the lead writers of the manuscript. MG and DLC performed retrospective clinical review and data analysis and MG reviewed and edited the manuscript. JC provided laboratory bench testing oversight and reviewed and edited the manuscript. 
We would like to thank Calgary Laboratory Services (now Alberta Precision Laboratories) for a peer-reviewed research grant to perform this work. The Provincial Laboratory Northern Alberta provided fungal isolates for this study.

\section{References}

1. Ford ES, Duke ER, Cheng GS, Yoke LM, Liu C, Hill JA, et al. Outcomes of Hematopoietic Cell Transplantation in Patients with Mixed Response to Pretransplantation Treatment of Confirmed or Suspected Invasive Fungal Infection. Transplant Cell Ther. 2021.

2. Tey A, Shaw B, Cardamone L, Shepherd S, Paul E, Rogers B, et al. Risk factors for invasive fungal infection in 5-azacytidine treated patients with acute myeloid leukemia and myelodysplastic syndrome. Eur J Haematol. 2021.

3. Rinaldi M, Bartoletti M, Ferrarese A, Franceschini E, Campoli C, Coladonato S, et al. Breakthrough invasive fungal infection after liver transplantation in patients on targeted antifungal prophylaxis: A prospective multicentre study. Transpl Infect Dis. 2021:e13608.

4. Li Y, Gao Y, Niu X, Wu Y, Du Y, Yang Y, et al. A 5-Year Review of Invasive Fungal Infection at an Academic Medical Center. Front Cell Infect Microbiol. 2020;10:553648.

5. Hosseini-Moghaddam SM, Ouedraogo A, Naylor KL, Bota SE, Husain S, Nash DM, et al. Incidence and outcomes of invasive fungal infection among solid organ transplant recipients: A population-based cohort study. Transpl Infect Dis. 2020;22(2):e13250.

6. Ferrarese A, Cattelan A, Cillo U, Gringeri E, Russo FP, Germani G, et al. Invasive fungal infection before and after liver transplantation. World J Gastroenterol. 2020;26(47):7485-96.

7. Kobayashi R, Hori D, Sano H, Suzuki D, Kishimoto K, Kobayashi K. Risk Factors for Invasive Fungal Infection in Children and Adolescents With Hematologic and Malignant Diseases: A 10-year Analysis in a Single Institute in Japan. Pediatr Infect Dis J. 2018;37(12):1282-5.

8. Corzo-Leon DE, Satlin MJ, Soave R, Shore TB, Schuetz AN, Jacobs SE, et al. Epidemiology and outcomes of invasive fungal infections in allogeneic haematopoietic stem cell transplant recipients in the era of antifungal prophylaxis: a single-centre study with focus on emerging pathogens. Mycoses. 2015;58(6):325-36.

9. Neofytos D, Horn D, Anaissie E, Steinbach W, Olyaei A, Fishman J, et al. Epidemiology and outcome of invasive fungal infection in adult hematopoietic stem cell transplant recipients: analysis of Multicenter Prospective Antifungal Therapy (PATH) Alliance registry. Clin Infect Dis. 2009;48(3):265-73.

10. Farmakiotis D, Kontoyiannis DP. Emerging issues with diagnosis and management of fungal infections in solid organ transplant recipients. Am J Transplant. 2015;15(5):1141-7.

11. Farmakiotis D, Kyvernitakis A, Tarrand JJ, Kontoyiannis DP. Early initiation of appropriate treatment is associated with increased survival in cancer patients with Candida glabrata fungaemia: a potential benefit from infectious disease consultation. Clin Microbiol Infect. 2015;21(1):79-86.

12. Garey KW, Rege M, Pai MP, Mingo DE, Suda KJ, Turpin RS, et al. Time to initiation of fluconazole therapy impacts mortality in patients with candidemia: a multi-institutional study. Clin Infect Dis. 2006;43(1):25-31.

13. Ambasta A, Carson J, Church DL. The use of biomarkers and molecular methods for the earlier diagnosis of invasive aspergillosis in immunocompromised patients. Med Mycol. 2015;53(6):531-57.

14. Arvanitis M, Anagnostou T, Fuchs BB, Caliendo AM, Mylonakis E. Molecular and nonmolecular diagnostic methods for invasive fungal infections. Clin Microbiol Rev. 2014;27(3):490-526.

15. Tarrand JJ, Lichterfeld M, Warraich I, Luna M, Han XY, May GS, et al. Diagnosis of invasive septate mold infections. A correlation of microbiological culture and histologic or cytologic examination. Am J Clin Pathol. 2003;119(6):854-8.

16. Lee S, Yun NR, Kim KH, Jeon JH, Kim EC, Chung DH, et al. Discrepancy between histology and culture in filamentous fungal infections. Med Mycol. 2010;48(6):886-8. 
17. Sangoi AR, Rogers WM, Longacre TA, Montoya JG, Baron EJ, Banaei N. Challenges and pitfalls of morphologic identification of fungal infections in histologic and cytologic specimens: a ten-year retrospective review at a single institution. Am J Clin Pathol. 2009;131(3):364-75.

18. Lass-Florl C, Mutschlechner W, Aigner M, Grif K, Marth C, Girschikofsky M, et al. Utility of PCR in diagnosis of invasive fungal infections: real-life data from a multicenter study. J Clin Microbiol. 2013;51(3):863-8.

19. Rampini SK, Zbinden A, Speck RF, Bloemberg GV. Similar efficacy of broad-range ITS PCR and conventional fungal culture for diagnosing fungal infections in non-immunocompromised patients. BMC Microbiol. 2016;16(1):132.

20. Zeller I, Schabereiter-Gurtner C, Mihalits V, Selitsch B, Barousch W, Hirschl AM, et al. Detection of fungal pathogens by a new broad range real-time PCR assay targeting the fungal ITS2 region. J Med Microbiol. 2017;66(10):1383-92.

21. Ala-Houhala M, Koukila-Kahkola P, Antikainen J, Valve J, Kirveskari J, Anttila VJ. Clinical use of fungal PCR from deep tissue samples in the diagnosis of invasive fungal diseases: a retrospective observational study. Clin Microbiol Infect. 2018;24(3):301-5.

22. Gomez CA, Budvytiene I, Zemek AJ, Banaei N. Performance of Targeted Fungal Sequencing for Culture-Independent Diagnosis of Invasive Fungal Disease. Clin Infect Dis. 2017;65(12):2035-41.

23. Valero C, de la Cruz-Villar L, Zaragoza O, Buitrago MJ. New Panfungal Real-Time PCR Assay for Diagnosis of Invasive Fungal Infections. J Clin Microbiol. 2016;54(12):2910-8.

24. Trubiano JA, Dennison AM, Morrissey CO, Chua KY, Halliday CL, Chen SC, et al. Clinical utility of panfungal polymerase chain reaction for the diagnosis of invasive fungal disease: a single center experience. Med Mycol. 2016;54(2):138-46.

25. Babouee B, Goldenberger D, Elzi L, Lardinois D, Sadowski-Cron C, Bubendorf L, et al. Prospective study of a panfungal PCR assay followed by sequencing, for the detection of fungal DNA in normally sterile specimens in a clinical setting: a complementary tool in the diagnosis of invasive fungal disease? Clin Microbiol Infect. 2013;19(8):E354-7.

26. Kommedal O, Simmon K, Karaca D, Langeland N, Wiker HG. Dual priming oligonucleotides for broad-range amplification of the bacterial 16S rRNA gene directly from human clinical specimens. J Clin Microbiol. 2012;50(4):1289-94.

27. Miller RJ, Chow B, Pillai D, Church D. Development and evaluation of a novel fast broad-range 16S ribosomal DNA PCR and sequencing assay for diagnosis of bacterial infective endocarditis: multi-year experience in a large Canadian healthcare zone and a literature review. BMC Infect Dis. 2016;16:146.

28. Donnelly JP CS, Kaffman CA, Steinbach WJ, Baddley JW, Verweij PR, Clancy CJ, Wingard JR, Lockhart SR, Groll AH, Sorrell TC, Bassetti M, Akan H, Alexander BD, Andes D, Azoulay E, Bialek R, Bradsher Jr BW, Bretagne S, Calndra T, Caliendo AM, Catagnola E, Cruciani M, Cuenca-Estrella M, Decker CF, Dessai SR, Fisher B, Harrison T, Heussel CP, Jensen HE, Kibbler CC, Kontoyiannis DP, Kullberg BJ, Lagrou K, Lamoth F, Lehrnbecher T, Loeffler, J, Lrtholary O, Maertens J, Marchetti O, Marr KA, Masur H, Meis JR, Morrisey CO, Nucci M, Ostrosky-Zeichner L, Pagano L, Patterson TF, Perfect JR, Racil Z, Roilides E, Ruhke M, Prokop CS, Shoham S, Slavin MA, Stevens DA, Thompson III GR, Vazquez JA, Viscoli C, Walsh TJ, Warris A, Wheat LJ, White PI, Zaoutis TE and Pappas PG. Revision and update of the consensus defintions of invasive fungal disease from the Euopean organization for research and treatment of cancer an the mycoses study group education and research consortium. Clin Infect Dis. 2020;71(6):1367-76.

29. Clnical Laboratory Standards Institute (CLSI). Interpretive criteria for identification of bacteria and funi by DNA target sequencing. Approved Guideline MM-18. Wayne, PA USA: CLSI; 2018.

30. Manji F LJ, Meatherall BL, Church D, Missaghi B. Severe facial necrosis in a type 1 diateic patient seconday to mucomycosis masquerading as an internal maxillary artery occlusion: a case report. BMC Infect Dis. 2019;19(1):184.

31. Stempak LM, Vogel SA, Richter SS, Wyllie R, Procop GW. Routine Broad-Range Fungal Polymerase Chain Reaction With DNA Sequencing in Patients With Suspected Mycoses Does Not Add Value and Is Not Cost-Effective. Arch Pathol Lab Med. 2019;143(5):634-8.

32. Jia B, Lovari R, Miller H, Metzgar D, Massire C, Carolan H, et al. Evaluation of a PCR-electrospray ionization mass spectrometry platform for detection and identification of fungal pathogens directly from prospectively collected bronchoalveolar lavage specimens. Diagn Microbiol Infect Dis. 2020;97(1):114988. 


\section{Tables}

Table 1

Clinical Specimens Tested in Validation of Broad Range Fungal PCR/Sequencing Assay

\begin{tabular}{|c|c|c|c|c|c|c|}
\hline $\begin{array}{l}\text { Fungal } \\
\text { Culture }^{a}\end{array}$ & $\begin{array}{l}\text { Bronchoalveolar } \\
\text { Lavages (BALs) }\end{array}$ & Lung/Bronchial/Pleural & $\begin{array}{l}\text { Cerebrospinal } \\
\text { Fluids (CSFs) }\end{array}$ & $\begin{array}{l}\text { Other } \\
\text { Sterile } \\
\text { Fluids }^{b}\end{array}$ & $\begin{array}{l}\text { Other Sterile } \\
\text { Tissues }^{c}\end{array}$ & TOTAL \\
\hline Positive & 34 & 3 & 2 & 9 & 7 & 55 \\
\hline Negative & 5 & 6 & 3 & 9 & 16 & 39 \\
\hline $\begin{array}{l}\text { Not } \\
\text { Ordered }\end{array}$ & 0 & 3 & 9 & 7 & 1 & 20 \\
\hline TOTAL & $39(34.2 \%)$ & $12(10.5 \%)$ & $14(12.3 \%)$ & $25(22 \%)$ & $24(21 \%)$ & 114 \\
\hline
\end{tabular}

aspecimens where fungal culture was not ordered but bacterial cultures grew yeast/fungi were counted as positive.

${ }^{b}$ No fungal culture was done on a CSF that tested negative for Cryptococcal antigen. Includes peritoneal/dialysates ( $\mathrm{n}=6$ ), synovial/spine disc $(n=5)$, abdominal $(n=5)$, sinus/nose aspirate $(n=4)$, liver abscess $(n=3)$, brain/subdural $(n=1)$ and periorbital $(n=1)$

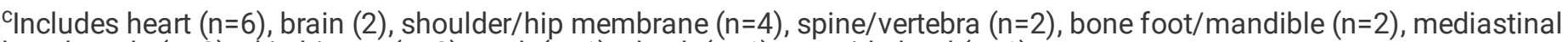
lymph node $(n=2)$, skin biopsy $(n=2)$, neck $(n=1)$, cheek $(n=1)$, parotid gland $(n=1)$. 
Table 2

A. Discrepant Clinical Specimens Resolved in Favour of Molecular Assay (True Positive or Negative by PCR/Sequencing)

\begin{tabular}{|c|c|c|c|c|c|c|}
\hline $\begin{array}{l}\text { Specimen } \\
\text { No. }\end{array}$ & $\begin{array}{l}\text { Specimen } \\
\text { Type }^{\text {a }}\end{array}$ & $\begin{array}{l}\text { Stain } \\
\text { Results }\end{array}$ & Fungal Culture & $\begin{array}{l}\text { Initial } \\
\text { Molecular } \\
\text { Results }\end{array}$ & $\begin{array}{l}\text { Sequence } \\
\text { Results }\end{array}$ & $\begin{array}{l}\text { Results of Resolution (Repeat } \\
\text { PCR and Clinical Review) }\end{array}$ \\
\hline 1 & BAL LUL & $\begin{array}{l}\text { CW=fungal } \\
\text { elements }\end{array}$ & $\begin{array}{l}\text { C. albicans, } A \text {. } \\
\text { fumigatus, } A \text {. } \\
\text { flavus }\end{array}$ & $\begin{array}{l}\text { ITS/LSU } \\
\text { targets } \\
\text { POS, } \beta- \\
\text { globin } \\
\text { POS }\end{array}$ & $\begin{array}{l}\text { ITS }=C . \\
\text { albicans } \\
\text { LSU }=C . \\
\text { albicans }\end{array}$ & $\begin{array}{l}\text { True positive PCR } \\
\text { Fungal culture contaminated }\end{array}$ \\
\hline 2 & BAL LLL & $\begin{array}{l}\text { Gram stain } \\
=\text { Hvy } \\
\text { WBCs + } \\
\text { mixed } \\
\text { bacteria; } \\
\text { CW=NEG }\end{array}$ & $\begin{array}{l}\text { Aspergillus } \\
\text { spp. }\end{array}$ & $\begin{array}{l}\text { ITS/LSU } \\
\text { targets } \\
\text { NEG, } \beta- \\
\text { globin } \\
\text { POS }\end{array}$ & $\mathrm{N} / \mathrm{A}$ & $\begin{array}{l}\text { True negative PCR } \\
\text { No pulmonary disease } \\
\text { Fungal culture contaminated }\end{array}$ \\
\hline 3 & BAL RLL & $\begin{array}{l}\text { Gram stain } \\
\text { - Hvy } \\
\text { WBCs; } \\
\text { CW=NEG }\end{array}$ & $\begin{array}{l}\text { Aspergillus } \\
\text { spp., } \\
\text { Penicillium } \\
\text { spp. }\end{array}$ & $\begin{array}{l}\text { ITS/LSU } \\
\text { targets } \\
\text { NEG, } \beta- \\
\text { globin } \\
\text { POS }\end{array}$ & $\mathrm{N} / \mathrm{A}$ & $\begin{array}{l}\text { True negative PCR } \\
\text { No pulmonary disease } \\
\text { Fungal culture contaminated }\end{array}$ \\
\hline 4 & BAL RUL & $\begin{array}{l}\text { Gram stain } \\
\text { - Hvy } \\
\text { WBCs; } \\
\text { CW=NEG }\end{array}$ & A. fumigatus & $\begin{array}{l}\text { ITS/LSU } \\
\text { targets } \\
\text { NEG, } \beta- \\
\text { globin } \\
\text { POS }\end{array}$ & $\mathrm{N} / \mathrm{A}$ & $\begin{array}{l}\text { True negative PCR } \\
\text { No pulmonary disease } \\
\text { Fungal culture contaminated }\end{array}$ \\
\hline 5 & BAL LLL & $\begin{array}{l}\text { Gram stain } \\
=\text { Hvy } \\
\text { WBCs; } \\
\text { CW=Hvy } \\
\text { yeast seen }\end{array}$ & $\begin{array}{l}\text { A. fumigatus, } \\
\text { dermatiaceous } \\
\text { fungus }\end{array}$ & $\begin{array}{l}\text { ITS/LSU } \\
\text { targets } \\
\text { POS, } \beta- \\
\text { globin } \\
\text { POS }\end{array}$ & $\begin{array}{l}\text { ITS = } \\
\text { Exophiala } \\
\text { dermatitidis } \\
\text { LSU = } \\
\text { Exophiala } \\
\text { dermatitidis }\end{array}$ & $\begin{array}{l}\text { True positive PCR } \\
\text { Other BAL samples grew } A \text {. } \\
\text { fumigatus, E. jeanselmi. } \\
\text { Interstitial pneumonia }\end{array}$ \\
\hline 6 & BAL RLL & $\begin{array}{l}\text { Gram stain } \\
= \\
\text { Hvy WBCs } \\
\text { + mixed } \\
\text { bacteria; } \\
\text { CW=NEG }\end{array}$ & A. fumigatus & $\begin{array}{l}\text { ITS/LSU } \\
\text { targets } \\
\text { POS } \\
\text { (weak), } \beta- \\
\text { globin } \\
\text { POS }\end{array}$ & $\begin{array}{l}\text { ITS }=A . \\
\text { fumigatus } \\
\text { LSU = } A . \\
\text { fumigatus }\end{array}$ & $\begin{array}{l}\text { True positive PCR } \\
\text { Clinical diagnosis of } \\
\text { pulmonary Aspergillosis. }\end{array}$ \\
\hline 7 & BAL LUL & $\begin{array}{l}\text { Gram stain } \\
=\text { Sct. } \\
\text { WBCs }+ \\
\text { mixed } \\
\text { bacteria; } \\
\text { CW=NEG }\end{array}$ & $\begin{array}{l}\text { C. albicans }+ \\
\text { oropharyngeal } \\
\text { flora }\end{array}$ & $\begin{array}{l}\text { ITS/LSU } \\
\text { targets } \\
\text { NEG, } \beta- \\
\text { globin } \\
\text { POS }\end{array}$ & $\mathrm{N} / \mathrm{A}$ & $\begin{array}{l}\text { True negative PCR } \\
\text { Pneumocystis jirovecii PCR } \\
\text { POS. }\end{array}$ \\
\hline 8 & BAL RLL & $\begin{array}{l}\text { Gram stain } \\
=\text { Hvy } \\
\text { WBCs; } \\
\text { CW=Hvy } \\
\text { yeast seen }\end{array}$ & $\begin{array}{l}\text { C. albicans, } \\
\text { yeast not } C \text {. } \\
\text { albicans }\end{array}$ & $\begin{array}{l}\text { ITS/LSU } \\
\text { targets } \\
\text { POS, } \beta- \\
\text { globin } \\
\text { POS }\end{array}$ & $\begin{array}{l}\text { Mixed } \\
\text { sequence: } \\
\text { ITS = C. } \\
\text { albicans } \\
\text { and } C \text {. } \\
\text { glabrata } \\
\text { LSU = C. } \\
\text { albicans } \\
\text { and C. } \\
\text { glabrata }\end{array}$ & $\begin{array}{l}\text { True positive PCR } \\
\text { Consistent with } \\
\text { oropharyngeal colonization } \\
\text { and overgrowth of Candida } \\
\text { spp. }\end{array}$ \\
\hline
\end{tabular}

${ }^{a}$ BAL samples were collected by pulmonary medicine or critical care specialists according to the Calgary Zone regional protocol. All other clinical samples were collected in the operating room or by interventional radiology under ultrasound guidance. 


\begin{tabular}{|c|c|c|c|c|c|c|}
\hline $\begin{array}{l}\text { Specimen } \\
\text { No. }\end{array}$ & $\begin{array}{l}\text { Specimen } \\
\text { Type }^{a}\end{array}$ & $\begin{array}{l}\text { Stain } \\
\text { Results }\end{array}$ & Fungal Culture & $\begin{array}{l}\text { Initial } \\
\text { Molecular } \\
\text { Results }\end{array}$ & $\begin{array}{l}\text { Sequence } \\
\text { Results }\end{array}$ & $\begin{array}{l}\text { Results of Resolution (Repeat } \\
\text { PCR and Clinical Review) }\end{array}$ \\
\hline \multirow[t]{3}{*}{9} & \multirow[t]{3}{*}{ BAL RLL } & \multirow[t]{3}{*}{$\begin{array}{l}\text { Gram stain } \\
=\text { Hvy } \\
\text { WBCs }+ \\
\text { mixed } \\
\text { bacteria; } \\
\text { CW=NEG }\end{array}$} & A. niger, & \multirow[t]{3}{*}{$\begin{array}{l}\text { ITS/LSU } \\
\text { targets } \\
\text { POS, } \beta- \\
\text { globin } \\
\text { POS }\end{array}$} & \multirow[t]{3}{*}{$\begin{array}{l}\text { ITS }=A \\
\text { niger } \\
\text { LSU }=A \\
\text { niger }\end{array}$} & True positive PCR \\
\hline & & & \multirow[t]{2}{*}{ A. fumigatus } & & & $\begin{array}{l}\text { Other BAL samples grew both } \\
\text { Aspergillus spp. }\end{array}$ \\
\hline & & & & & & $\begin{array}{l}\text { Clinical diagnosis of airway } \\
\text { colonization. }\end{array}$ \\
\hline \multirow[t]{3}{*}{10} & \multirow[t]{3}{*}{ BAL RLL } & \multirow{3}{*}{$\begin{array}{l}\text { Gram stain } \\
= \\
\text { Hvy WBCs } \\
+ \text { mixed } \\
\text { bacteria; } \\
\text { CW=NEG }\end{array}$} & \multirow{3}{*}{$\begin{array}{l}\text { C. albicans, } \\
\text { A. fumigatus }\end{array}$} & \multirow{3}{*}{$\begin{array}{l}\text { ITS/LSU } \\
\text { targets } \\
\text { POS, } \beta- \\
\text { globin } \\
\text { POS }\end{array}$} & \multirow{3}{*}{$\begin{array}{l}\text { ITS }=C . \\
\text { albicans } \\
\text { LSU }=C . \\
\text { albicans }\end{array}$} & True positive PCR \\
\hline & & & & & & $\begin{array}{l}\text { Clinical diagnosis of } \\
\text { metapneumovirus/enterovirus } \\
\text { infection. }\end{array}$ \\
\hline & & & & & & $\begin{array}{l}\text { C. albicans consistent with } \\
\text { airway colonization; } A \text {. } \\
\text { fumigatus contaminant. }\end{array}$ \\
\hline \multirow[t]{3}{*}{11} & \multirow[t]{3}{*}{ Brain tissue } & \multirow{3}{*}{$\begin{array}{l}\text { Gram stain } \\
\text { - Hvy } \\
\text { WBCs; } \\
\text { CW=NEG }\end{array}$} & \multirow{3}{*}{$\begin{array}{l}\text { No growth } \\
\text { after } 4 \text { weeks }\end{array}$} & ITS POS & \multirow{2}{*}{$\begin{array}{l}\text { ITS: } \\
\text { Rhizopus } \\
\text { oryzae }\end{array}$} & True positive PCR \\
\hline & & & & LSU NEG & & $\begin{array}{l}\text { Pathology sections positive } \\
\text { for broad aseptate hyphae. }\end{array}$ \\
\hline & & & & $\begin{array}{l}\beta \text {-globin } \\
\text { POS }\end{array}$ & $\begin{array}{l}\text { LSU: No } \\
\text { data }\end{array}$ & $\begin{array}{l}\text { Clinical diagnosis of } \\
\text { rhinocerebral mucormycosis }\end{array}$ \\
\hline \multirow[t]{4}{*}{12} & \multirow[t]{4}{*}{ Cheek tissue } & \multirow{4}{*}{$\begin{array}{l}\text { CW=fungal } \\
\text { elements }\end{array}$} & \multirow{4}{*}{$\begin{array}{l}\text { No growth } \\
\text { after } 6 \text { weeks }\end{array}$} & ITS POS & \multirow{2}{*}{$\begin{array}{l}\text { ITS: } \\
\text { Rhizopus } \\
\text { oryzae }\end{array}$} & True positive PCR \\
\hline & & & & LSU POS & & \multirow{3}{*}{$\begin{array}{l}\text { Pathology PAS and GMS } \\
\text { section stains showed broad } \\
\text { aseptate hyphae. } \\
\text { Clinical diagnosis of } \\
\text { rhinocerebral mucormycosis }\end{array}$} \\
\hline & & & & $\begin{array}{l}\beta \text {-globin } \\
\text { POS }\end{array}$ & $\begin{array}{l}\text { LSU: } \\
\text { Rhizopus }\end{array}$ & \\
\hline & & & & & oryzae & \\
\hline \multirow[t]{4}{*}{13} & \multirow[t]{4}{*}{$\begin{array}{l}\text { Parotid gland } \\
\text { tissue }\end{array}$} & \multirow[t]{4}{*}{$\begin{array}{l}\text { CW=no } \\
\text { fungal } \\
\text { elements }\end{array}$} & \multirow[t]{4}{*}{ C. albicans } & ITS POS & $\begin{array}{l}\text { ITS: } \\
\text { Rhizopus } \\
\text { oryzae }\end{array}$ & \multirow[t]{2}{*}{ True positive PCR } \\
\hline & & & & & $\begin{array}{l}\text { LSU: } \\
\text { Rhizopus } \\
\text { oryzae }\end{array}$ & \\
\hline & & & & LSU POS & & \multirow{2}{*}{$\begin{array}{l}\text { Clinical diagnosis of } \\
\text { rhinocerebral mucormycosis }\end{array}$} \\
\hline & & & & $\begin{array}{l}\beta \text {-globin } \\
\text { POS }\end{array}$ & & \\
\hline
\end{tabular}

aBAL samples were collected by pulmonary medicine or critical care specialists according to the Calgary Zone regional protocol. All other clinical samples were collected in the operating room or by interventional radiology under ultrasound guidance. 


\begin{tabular}{|c|c|c|c|c|c|c|}
\hline $\begin{array}{l}\text { Specimen } \\
\text { No. }\end{array}$ & $\begin{array}{l}\text { Specimen } \\
\text { Type }^{a}\end{array}$ & $\begin{array}{l}\text { Stain } \\
\text { Results }\end{array}$ & Fungal Culture & $\begin{array}{l}\text { Initial } \\
\text { Molecular } \\
\text { Results }\end{array}$ & $\begin{array}{l}\text { Sequence } \\
\text { Results }\end{array}$ & $\begin{array}{l}\text { Results of Resolution (Repeat } \\
\text { PCR and Clinical Review) }\end{array}$ \\
\hline 14 & Sinus tract fluid & $\begin{array}{l}\text { Gram stain } \\
=\text { Hvy } \\
\text { WBCs with } \\
\text { mixed } \\
\text { bacteria } \\
\text { including } \\
\text { yeast }\end{array}$ & C. albicans & $\begin{array}{l}\text { ITS POS } \\
\text { LSU POS } \\
\text { ß-globin } \\
\text { POS }\end{array}$ & $\begin{array}{l}\text { ITS: } C \text {. } \\
\text { glabrata } \\
\text { LSU: } C \text {. } \\
\text { glabrata }\end{array}$ & $\begin{array}{l}\text { True positive PCR } \\
\text { MALDI-TOF MS confirmed } C \text {. } \\
\text { glabrata and isolate had } \\
\text { elevated fluconazole MIC. } \\
\text { Fungal culture initially mis- } \\
\text { identified. }\end{array}$ \\
\hline 15 & $\begin{array}{l}\text { Abdominal } \\
\text { abscess } \\
\text { tissue/fluid }\end{array}$ & $\begin{array}{l}\text { Gram stain } \\
=\text { Hvy } \\
\text { WBCs }+ \\
\text { mixed } \\
\text { bacteria; } \\
\text { CW=NEG }\end{array}$ & $\begin{array}{l}\text { No growth } \\
\text { after } 6 \text { weeks }\end{array}$ & $\begin{array}{l}\text { ITS POS } \\
\text { LSU POS } \\
\text { ß-globin } \\
\text { POS }\end{array}$ & $\begin{array}{l}\text { ITS: } C \text {. } \\
\text { albicans } \\
\text { LSU: } C \text {. } \\
\text { albicans }\end{array}$ & $\begin{array}{l}\text { True positive PCR } \\
\text { Clinical diagnosis of intra- } \\
\text { abdominal abscess. }\end{array}$ \\
\hline 16 & $\begin{array}{l}\text { Shoulder tissue } \\
\text { (intermedullary) }\end{array}$ & $\begin{array}{l}\text { Gram stain } \\
-=\text { Hvy } \\
\text { WBCs; } \\
\text { CW=NEG }\end{array}$ & Alternaria spp. & $\begin{array}{l}\text { ITS NEG } \\
\text { LSU NEG } \\
\text { ß-globin } \\
\text { POS }\end{array}$ & $\mathrm{N} / \mathrm{A}$ & $\begin{array}{l}\text { True negative PCR } \\
\text { Clinical diagnosis of } \\
\text { Cutibacterium acnes joint } \\
\text { infection. } \\
\text { Fungal culture contaminated. }\end{array}$ \\
\hline 17 & $\mathrm{R}$ hip tissue & $\begin{array}{l}\text { Gram stain } \\
=\text { No } \\
\text { WBCs; } \\
\text { CW=NEG }\end{array}$ & $\begin{array}{l}\text { Environmental } \\
\text { fungus } \\
\text { isolated (not } \\
\text { further } \\
\text { identified at } \\
\text { reference } \\
\text { laboratory) }\end{array}$ & $\begin{array}{l}\text { ITS weak } \\
\text { band } \\
\text { LSU weak } \\
\text { band } \\
\text { B-globin } \\
\text { POS }\end{array}$ & $\begin{array}{l}\text { ITS: poor } \\
\text { sequence } \\
\text { LSU: poor } \\
\text { sequence }\end{array}$ & $\begin{array}{l}\text { True negative PCR } \\
\text { No evidence of IFD } \\
\text { Fungal culture contaminated }\end{array}$ \\
\hline 18 & Liver aspirate & $\begin{array}{l}\text { Gram stain } \\
=\text { no } \\
\text { WBCS; } \\
\text { CW=NEG }\end{array}$ & $\begin{array}{l}\text { No growth } \\
\text { after } 4 \text { weeks }\end{array}$ & $\begin{array}{l}\text { ITS POS } \\
\text { LSU POS } \\
\text { B-globin } \\
\text { POS }\end{array}$ & $\begin{array}{l}\text { ITS: } \\
\text { Rhizomucor } \\
\text { pusillus. } \\
\text { LSU: } \\
\text { Rhizomucor } \\
\text { pusillus. }\end{array}$ & $\begin{array}{l}\text { True positive PCR } \\
\text { Pathology sections positive } \\
\text { for broad aseptate hyphae. } \\
\text { Clinical diagnosis of } \\
\text { hepatosplenic mucormycosis }\end{array}$ \\
\hline 19 & $\begin{array}{l}\text { Lung } \\
\text { tissue/fluid }\end{array}$ & $\begin{array}{l}\text { Gram stain } \\
=\text { Few } \\
\text { WBCs; } \\
\text { CW=NEG }\end{array}$ & $\begin{array}{l}\text { No growth } \\
\text { after } 6 \text { weeks }\end{array}$ & $\begin{array}{l}\text { ITS POS } \\
\text { LSU POS } \\
\text { ß-globin } \\
\text { POS }\end{array}$ & $\begin{array}{l}\text { ITS: } \\
\text { Histoplasma } \\
\text { capsulatum } \\
\text { LSU: No } \\
\text { data }\end{array}$ & $\begin{array}{l}\text { True positive PCR } \\
\text { Pathology of lung tissue } \\
\text { showed necrotizing } \\
\text { granulomas with yeast } \\
\text { morphologically consistent. } \\
\text { Clinical diagnosis of } \\
\text { Histoplasmosis }\end{array}$ \\
\hline
\end{tabular}


Table 2

B. Discrepant Clinical Specimens Resolved in Favour of Conventional Testing (False Positive or Negative by PCR/Sequencing)

\begin{tabular}{|c|c|c|c|c|c|c|}
\hline $\begin{array}{l}\text { Specimen } \\
\text { No. }\end{array}$ & $\begin{array}{l}\text { Specimen } \\
\text { Type }^{\text {a }}\end{array}$ & $\begin{array}{l}\text { Stain } \\
\text { Results }\end{array}$ & $\begin{array}{l}\text { Fungal } \\
\text { Culture }\end{array}$ & $\begin{array}{l}\text { Initial } \\
\text { Molecular } \\
\text { Results }\end{array}$ & Sequence Results & $\begin{array}{l}\text { Results of Clinical } \\
\text { Review }\end{array}$ \\
\hline 1 & BAL LUL & $\begin{array}{l}\mathrm{CW}= \\
\text { fungal } \\
\text { elements }\end{array}$ & Negative & $\begin{array}{l}\text { ITS/LSU } \\
\text { targets } \\
\text { POS, } \beta \text { - } \\
\text { globin POS }\end{array}$ & $\begin{array}{l}\text { LSU = Oxyporus } \\
\text { corticola } \\
\text { Repeat testing using } \\
\text { conventional ITS } \\
\text { primers showed } A \text {. } \\
\text { terreus. }\end{array}$ & $\begin{array}{l}\text { False positive PCR } \\
\text { No pulmonary } \\
\text { disease }\end{array}$ \\
\hline 2 & BAL RLL & $\begin{array}{l}\mathrm{CW}=\text { no } \\
\text { fungal } \\
\text { elements }\end{array}$ & $\begin{array}{l}\text { C. albicans, } \\
\text { A. flavus }\end{array}$ & $\begin{array}{l}\text { ITS/LSU } \\
\text { targets } \\
\text { NEG, } \beta \text { - } \\
\text { globin POS } \\
\text { (weak) }\end{array}$ & $\mathrm{N} / \mathrm{A}$ & $\begin{array}{l}\text { False negative PCR } \\
\text { No pulmonary } \\
\text { disease. Repeat } \\
\text { testing gave same } \\
\text { results. Likely sample } \\
\text { deficiency. }\end{array}$ \\
\hline 3 & BAL LLL & $\begin{array}{l}\text { Gram } \\
\text { stain - } \\
\text { Hvy } \\
\text { WBCs; } \\
\text { CW=NEG }\end{array}$ & $\begin{array}{l}\text { C. } \\
\text { dublinensis, } \\
\text { A fumigatus }\end{array}$ & $\begin{array}{l}\text { ITS/LSU } \\
\text { targets } \\
\text { POS; } \beta \text { - } \\
\text { globin POS }\end{array}$ & $\begin{array}{l}\text { Sequencing } \\
\text { indeterminate as } \\
\text { mixed sequences } \\
\text { could not be resolved } \\
\text { for accurate } \\
\text { identification. }\end{array}$ & $\begin{array}{l}\text { Indeterminate PCR } \\
\text { Mixed sequences } \\
\text { Clinical diagnosis of } \\
\text { Aspergillosis. }\end{array}$ \\
\hline 4 & BAL LUL & $\begin{array}{l}\text { Gram } \\
\text { stain - } \\
\text { Hvy } \\
\text { WBCs; } \\
\text { CW=NEG }\end{array}$ & $\begin{array}{l}\text { C. glabrata, } \\
\text { A. terreus }\end{array}$ & $\begin{array}{l}\text { ITS/LSU } \\
\text { targets } \\
\text { POS; } \beta \text { - } \\
\text { globin POS }\end{array}$ & $\begin{array}{l}\mathrm{ITS}=\text { C. glabrata } \\
\mathrm{LSU}=\text { C. glabrata }\end{array}$ & $\begin{array}{l}\text { False negative PCR } \\
\text { Clinical diagnosis of } \\
\text { invasive Aspergillosis } \\
\text { with cavitary lung } \\
\text { lesion. }\end{array}$ \\
\hline 5 & BAL & $\begin{array}{l}\text { Gram } \\
\text { stain } \\
\text { and } \\
\text { CW=NEG }\end{array}$ & C. glabrata & $\begin{array}{l}\text { ITS POS } \\
\text { (weak)/LSU } \\
\text { target NEG, } \\
\beta \text {-globin } \\
\text { POS }\end{array}$ & $\begin{array}{l}\text { ITS (short sequence) = } \\
\text { Fusarium } \\
\text { merismoides, a plant } \\
\text { pathogen. }\end{array}$ & $\begin{array}{l}\text { False positive PCR } \\
\text { Clinical diagnosis of } \\
\text { primary lung } \\
\text { adenocarcinoma. }\end{array}$ \\
\hline 6 & BAL RML & $\begin{array}{l}\text { Gram } \\
\text { stain = } \\
\text { Hvy } \\
\text { WBCs; } \\
\text { CW=NEG }\end{array}$ & C. albicans & $\begin{array}{l}\text { ITS/LSU } \\
\text { targets } \\
\text { NEG, } \beta \text { - } \\
\text { globin POS }\end{array}$ & $\mathrm{N} / \mathrm{A}$ & $\begin{array}{l}\text { False negative PCR } \\
\text { Clinical diagnosis of } \\
\text { aspiration } \\
\text { pneumonia. C. } \\
\text { albicans consistent } \\
\text { with airway } \\
\text { colonization. }\end{array}$ \\
\hline
\end{tabular}

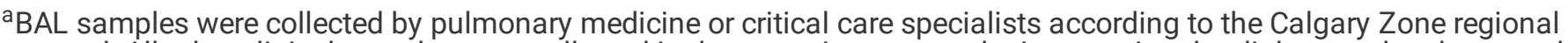
protocol. All other clinical samples were collected in the operating room or by interventional radiology under ultrasound guidance. 


\begin{tabular}{|c|c|c|c|c|c|c|}
\hline $\begin{array}{l}\text { Specimen } \\
\text { No. }\end{array}$ & $\begin{array}{l}\text { Specimen } \\
\text { Type }^{a}\end{array}$ & $\begin{array}{l}\text { Stain } \\
\text { Results }\end{array}$ & $\begin{array}{l}\text { Fungal } \\
\text { Culture }\end{array}$ & $\begin{array}{l}\text { Initial } \\
\text { Molecular } \\
\text { Results }\end{array}$ & Sequence Results & $\begin{array}{l}\text { Results of Clinical } \\
\text { Review }\end{array}$ \\
\hline 7 & CSF & $\begin{array}{l}\text { Gram } \\
\text { stain }= \\
\text { few } \\
\text { yeast }\end{array}$ & $\begin{array}{l}\text { Cryptococcus } \\
\text { neoformans }\end{array}$ & $\begin{array}{l}\text { ITS NEG } \\
\text { LSU NEG } \\
\text { B-globin } \\
\text { POS (weak) }\end{array}$ & $\mathrm{N} / \mathrm{A}$ & $\begin{array}{l}\text { False-negative PCR } \\
\text { Repeat } \\
\text { PCR/Sequencing } \\
\text { Negative } \\
\text { Likely sample } \\
\text { deficiency given } \\
\text { weak } \beta \text {-globin band. }\end{array}$ \\
\hline 8 & Bone(mandible) & $\begin{array}{l}\text { Gram } \\
\text { stain = } \\
\text { few } \\
\text { bacteria; } \\
\text { CW = } \\
\text { NEG }\end{array}$ & C. albicans & $\begin{array}{l}\text { ITS NEG } \\
\text { LSU NEG } \\
\beta \text {-globin } \\
\text { POS (weak) }\end{array}$ & $\mathrm{N} / \mathrm{A}$ & $\begin{array}{l}\text { False negative PCR } \\
\text { Repeat } \\
\text { PCR/Sequencing } \\
\text { Negative } \\
\text { Likely sample } \\
\text { deficiency given } \\
\text { weak } \beta \text {-globin band. }\end{array}$ \\
\hline 9 & Peritoneal fluid & $\begin{array}{l}\text { Gram } \\
\text { stain - } \\
\text { Hvy } \\
\text { WBCs; } \\
\text { CW=NEG }\end{array}$ & A. flavus & $\begin{array}{l}\text { ITS NEG } \\
\text { LSU NEG } \\
\beta \text {-globin } \\
\text { POS }\end{array}$ & $\mathrm{N} / \mathrm{A}$ & $\begin{array}{l}\text { False negative PCR } \\
\text { Repeat } \\
\text { PCR/Sequencing ITS } \\
\text { POS/LSU POS with } \\
\text { Aspergillus spp. split } \\
\text { identification. }\end{array}$ \\
\hline 10 & Dialysate fluid & $\begin{array}{l}\text { Gram } \\
\text { stain = } \\
\text { Hvy } \\
\text { WBCs; } \\
\text { CW not } \\
\text { done }\end{array}$ & C. tropicalis & $\begin{array}{l}\text { ITS NEG } \\
\text { LSU NEG } \\
\text { ß-globin } \\
\text { POS }\end{array}$ & $\mathrm{N} / \mathrm{A}$ & $\begin{array}{l}\text { False negative PCR } \\
\text { Repeat } \\
\text { PCR/Sequencing } \\
\text { Negative } \\
\text { Fungal culture of } \\
\text { other samples grew } \\
\text { same organism. }\end{array}$ \\
\hline 11 & Lung tissue & $\begin{array}{l}\text { Gram } \\
\text { stain = } \\
\text { Hvy } \\
\text { WBCs; } \\
\text { CW=NEG }\end{array}$ & $\begin{array}{l}\text { Coccidiodes } \\
\text { immitis }\end{array}$ & $\begin{array}{l}\text { ITS NEG } \\
\text { LSU NEG } \\
\text { ß-globin } \\
\text { POS }\end{array}$ & N/A & $\begin{array}{l}\text { False negative PCR } \\
\text { Clinical diagnosis of } \\
\text { pulmonary } \\
\text { Coccidioidomycosis. }\end{array}$ \\
\hline
\end{tabular}

Table 3A. Performance of Molecular Assay and Fungal Culture for Bronchoalveolar Lavage Specimens (Clinical and Contrived) ${ }^{a}$ 


\begin{tabular}{|c|c|c|c|c|}
\hline & & \multicolumn{3}{|c|}{ Fungal Culture } \\
\hline & & Positive & Negative & TOTAL \\
\hline \multirow[t]{3}{*}{ FBR-PCR/S Assayb } & Positive & 54 & 0 & 54 \\
\hline & Negative & 7 & 11 & 18 \\
\hline & TOTAL & 61 & 11 & 72 \\
\hline \multicolumn{5}{|c|}{ bensitivity $(88.5 \%, 54 / 61)$, specificity $(100 \%, 11 / 11)$, PPV $(100 \%, 54 / 54)$, NPV $(61.1 \%, 11 / 18)$ and efficiency $90.2 \%(65 / 72)$} \\
\hline & & \multicolumn{3}{|c|}{ FBR-PCR/S Assay } \\
\hline & & Positive & Negative & TOTAL \\
\hline \multirow[t]{3}{*}{ Fungal Culture ${ }^{c}$} & Positive & 54 & 7 & 61 \\
\hline & Negative & 0 & 11 & 11 \\
\hline & TOTAL & 54 & 18 & 72 \\
\hline \multicolumn{5}{|c|}{${ }^{\mathrm{c}}$ Sensitivity $(100 \%, 54 / 54)$, specificity $(61.1 \%, 11 / 18), \operatorname{PPV}(88.5 \%, 54 / 61)$, NPV $(100 \%, 11 / 11)$ and efficiency $90.2 \%(65 / 72)$} \\
\hline
\end{tabular}

ancludes 39 clinical specimens and 33 contrived specimens inoculated with a variety of fungal isolates identified by the reference lab. The molecular assay detected and accurately identified all fungal isolates in contrived BALs. PPV - positive predictive value, NPV - negative predictive value.

Table 3B. Performance of Molecular Assay and Fungal Culture for Other Types of Clinical Specimens (non-BALs) ${ }^{a}$

\begin{tabular}{|c|c|c|c|c|}
\hline & & \multicolumn{3}{|c|}{ Fungal Culture } \\
\hline & & Positive & Negative & TOTAL \\
\hline \multirow{5}{*}{ FBR-PCR/S Assayb } & Positive & 14 & 7 & 21 \\
\hline & Negative & 7 & 47 & 54 \\
\hline & TOTAL & 21 & 54 & 75 \\
\hline & & \multicolumn{3}{|c|}{ FBR-PCR/S Assay } \\
\hline & & Positive & Negative & TOTAL \\
\hline \multirow[t]{3}{*}{ Fungal Culture } & Positive & 14 & 7 & 21 \\
\hline & Negative & $7^{a}$ & 47 & 54 \\
\hline & TOTAL & 21 & 54 & 75 \\
\hline
\end{tabular}

ancludes all non-BAL clinical specimens tested. Molecular assay results were resolved by clinical review and repeat testing. 7 specimens that were FBR-PCR/S(+)/fungal culture(-) were resolved after clinical review to be true positive molecular tests and false negative cultures. See Table 2A and 2B.

Table 3C. Performance of Molecular Assay and Fungal Culture Compared to Microscopy for Clinical Specimens including Contrived BALs ${ }^{a}$ 


\begin{tabular}{|c|c|c|c|c|}
\hline & & \multicolumn{3}{|c|}{ CW Stain/Microscopy } \\
\hline & & Positive & Negative & TOTAL \\
\hline \multirow[t]{3}{*}{ FBR-PCR/S Assayb } & Positive & 8 & 42 & 50 \\
\hline & Negative & 2 & 62 & 64 \\
\hline & TOTAL & 10 & 104 & 114 \\
\hline \multicolumn{5}{|c|}{ bSensitivity $(80 \%, 8 / 10)$, specificity $(59.6 \%, 62 / 104), \operatorname{PPV}(16 \%, 8 / 50), \mathrm{NPV}(96.9 \%, 62 / 64)$ and efficiency $61.4 \%(70 / 114)$} \\
\hline & & \multicolumn{3}{|c|}{ CW Stain/Microscopy } \\
\hline & & Positive & Negative & TOTAL \\
\hline \multirow[t]{3}{*}{ Fungal Culture ${ }^{c}$} & Positive & 8 & 51 & 59 \\
\hline & Negative & 2 & 53 & 55 \\
\hline & TOTAL & 10 & 104 & 114 \\
\hline
\end{tabular}

ancludes the results of all BALs and clinical specimens enrolled in the study.

\section{Figures}




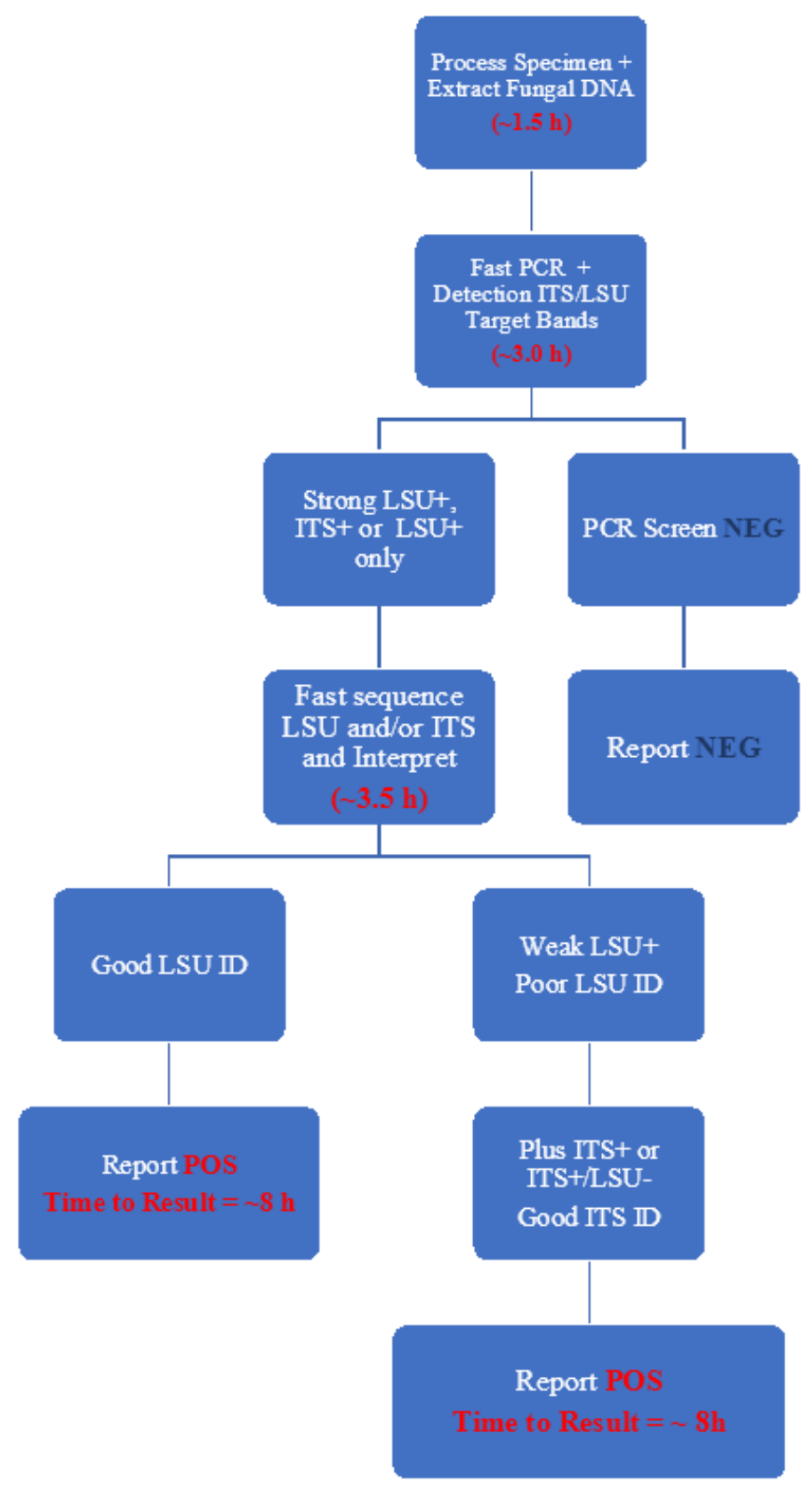

Figure 1

Algorithm for FBR-PCS/S Assay with Timing for Key Steps 